\title{
Poisoning in Sheep from Emory Milkretch and Nitro Compounds
}

\section{COBURN WILLIAMS AND LYNN F. JAMES}

Highlight: Sheep were fed nitro-containing Emory milkvetch (Astragalus emoryanus) and infused intravenously with 3-nitro--1-propanol and 3-nitropropanoic acid. Emory milkvetch and the nitro compounds produced similar clinical syndromes. Nitro compounds, therefore, appear to be the principal toxic constituent in Emory milkvetch.

Emory milkvetch (Astragalus emoryanus Rydb.) Cory), also called peavine, red-stemmed peavine, or Emory loco, is a poisonous milkvetch found in Texas, New Mexico, and

Authors are research plant physiologist and research animal scientist, Agricultural Research Service, U.S. Department of Agriculture, Logan, Utah 84322 .

The study was a cooperative investigation of the Agr. Res. Serv., U.S. Dep. Agr., and the Utah Agricultural Experiment Station, Logan, Utah. Utah Agricultural Experiment Station Journal Series No. 1966. Manuscript received May 2, 1975. adjacent areas of Mexico (Sperry et al., 1964). This annual or winter annual species is most abundant and troublesome in western Texas and the southern half of New Mexico. The species consists of two varieties, var. emoryanus, the most common and widespread, and Big Bend milkvetch, var. terlinguensis (Cory) Barneby, which grows locally in Presidio and Brewster counties, Texas.

Mathews (1940) described clinical signs of Emory milkvetch poisoning in sheep, cattle, and goats. The syndrome included momentary collapse of leg muscles, incoordination with knuckling over of fetlocks, especially in the hind quarters, loss of weight, rasping noise due to labored respiration, and paralysis. He further noted that these toxic signs were similar to those reported for $A$. tetrapterus Gray; timber milkvetch (A. hylophilus) in Colorado; and timber 


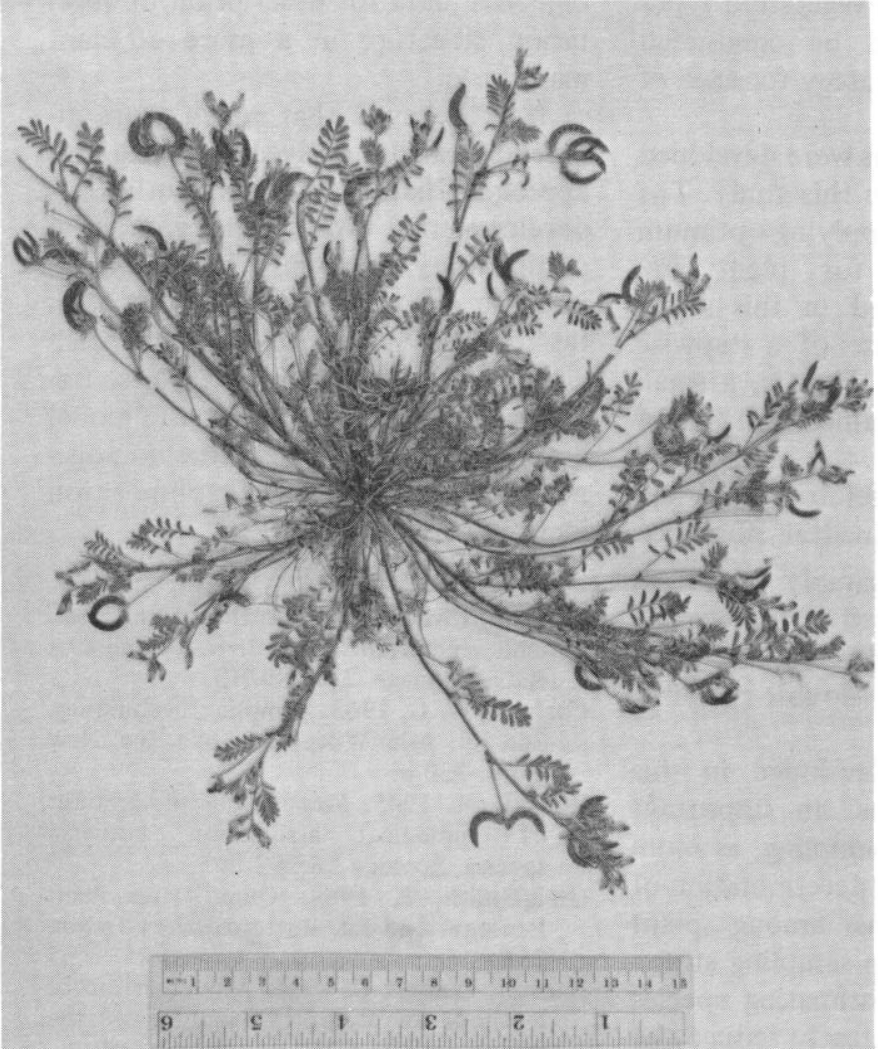

Fig. 1. Emory milkvetch, Astragalus emoryanus var. emoryanus, collected near Roswell, New Mexico. This nitro-bearing species is poisonous to cattle and sheep.

milkvetch (Astragalus miser var. oblongifolius Rydb.) Cron.) and Columbia milkvetch ( $A$. miser var. serotinus (Gray) Barneby), respectively. Organic nitro compounds have been identified as the poisonous compounds in Wasatch milkvetch (Stermitz et al., 1969), Columbia milkvetch (Williams and Norris, 1969), and A. tetrapterus (Williams and James, 1975).

Stermitz et al. (1969) reported the isolation of the $\beta$-glycoside of 3-nitro-1-propanol (3-NPOH) from Wasatch milkvetch. This compound, named miserotoxin, hydrolized to glucose and $3-\mathrm{NPOH}$ in the rumen of cattle and sheep (Williams et al., 1970). The 3-NPOH proved to be the toxic compound. Subsequent investigations revealed that nitro compounds occurred in at least 56 species of North American Astragalus, including Emory milkvetch (Williams and Parker, 1974).

Harlow et al. (1975) identified six nitro compounds in Astragalus flexuosus (Hook.) Don: miserotoxin, cibarian, karakin, hiptagin, 3-NPOH, and 3-nitropropanoic acid (3-NPA). Upon hydrolysis, cibarian, karakin, and hiptagin yielded 3-NPA. We found 3-NPOH more toxic than 3-NPA to cattle and sheep (Williams and James, 1975). Plants that synthesized primarily miserotoxin or $3-\mathrm{NPOH}$ tended to be more toxic per mg of $\mathrm{NO}_{2}$ than those in which 3-NPA or the glycosides of 3-NPA predominated.

The clinical signs reported in poisoning from Emory milkvetch were similar to those reported in Astragalus in which nitro compounds are known to be the toxic agent. This study was initiated to examine peavine for nitro content and to compare the toxicity and clinical signs of 3-NPOH, 3-NPA, and Emory milkvetch in sheep.

\section{Materials and Methods}

Emory milkvetch in the pod stage of growth was collected in June 1972 near Ft. Stanton, Lincoln County, New Mexico, where the plant frequently caused cattle losses. The plants were dried, shipped to the U.S. Department of Agriculture Poisonous Plant Research Laboratory at Logan, Utah, ground to 20 -mesh, and stored at $2^{\circ} \mathrm{C}$. A nitro analysis in the summer of 1973 yielded $8.0 \mathrm{mg} \mathrm{NO} / \mathrm{g}$ of plant. A second analysis before feeding in September 1974 yielded $5.8 \mathrm{mg} \mathrm{NO}_{2} / \mathrm{g}$.

A $59.6-\mathrm{kg}$ ewe was fed $400 \mathrm{~g}$ of the Ft. Stanton Emory milkvetch ( $38.9 \mathrm{mg} \mathrm{NO}_{2} / \mathrm{kg}$ of body weight) for 7 days, excluding Saturday and Sunday. The plant was mixed with water and fed via a stomach pump each morning, after which the animal received alfalfa hay and water free choice for the rest of the day. Blood was drawn from the jugular vein for methemoglobin determination (Evelyn and Malloy, 1938) 3 hours after feeding on the first and third days.

Four ewes were infused intravenously for 1 hour with organic nitro compounds in sterile saline at $20 \mathrm{mg} \mathrm{NO} / 2 \mathrm{~kg}$ of body weight. Two sheep received $3-\mathrm{NPOH}$ and two received 3-NPA. After infusion ceased, blood samples were taken hourly for 5 hours for methemoglobin determinations.

\section{Results and Discussion}

The sheep fed Emory milkvetch became weak and unsteady in the hindquarters on the sixth day of feeding. After feeding on the seventh day, the animal rapidly became weaker, and incoordination of the hindquarters was more pronounced. The animal urinated frequently, especially if disturbed. In early afternoon, the animal collapsed and lay with labored and audible respiration. When the sheep was forced to stand, all four fetlocks knuckled over. The sheep became paralyzed and was euthanatized for post-mortem examination when it seemed likely it would die during the night. Methemoglobin was $4.6 \%$ of total hemoglobin on the first day of feeding and $4.3 \%$ on the third. A significant increase in blood methemoglobin after the animal eats Astragalus suggests the absorption of nitro compounds.

This initial feeding exhausted our supply of Ft. Stanton Emory milkvetch and prevented the feeding of a second sheep. No collection of Emory milkvetch was made in 1973 because nitro compounds in the species were discovered after the plants had seeded and died. Because of a severe drought in New Mexico in 1974, Emory milkvetch was virtually nonexistent.

Sheep administered 3-NPA intravenously at $20 \mathrm{mg} \mathrm{NO} / \mathrm{kg}$ became depressed and incoordinated in the hindquarters 3 hours after treatment. Twenty-four hours later one sheep was weak and very incoordinated in the hindquarters, and it fell frequently. When it arose, its fetlocks knuckled over. The animal was euthanatized for post-mortem examination. The second sheep was stiff legged and slightly incoordinated at 24 hours, so it was infused a second time with 3-NPA at $20 \mathrm{mg}$ $\mathrm{NO}_{2} / \mathrm{kg}$. The animal died later in the day after showing the same clinical signs observed in the first sheep.

Sheep infused with 3-NPOH became weak and incoordinated in the hindquarters 2 hours after treatment. The animals urinated more frequently than normal. No knuckling of the fetlocks was noted. Respiration was labored and audible; the sound was associated with froth and mucous that collected in the air passages. Both animals collapsed and died about 4 hours after treatment. Methemoglobin in the blood of sheep infused with 3-NPOH and 3-NPA reached only 2.1 to $2.5 \%$. Apparently, little nitrite was split from the 3-carbon side chain to form methemoglobin.

The toxic signs produced in sheep with Emory milkvetch and 3-NPA appear identical. The syndrome produced by 3-NPOH was similar to that produced by 3-NPA except that the time lapse between the onset of toxic signs and collapse and paralysis was very rapid and the knuckled fetlock stage was not evident. 
High-pressure liquid chromatography of Emory milkvetch (var. emoryanus) produced a distribution of nitro compounds, expressed as $\mathrm{NO}_{2}$, as follows: miserotoxin, $22 \%$; cibarian, $35 \%$; karakin, $11 \%$; hiptagin, $12 \%$; and $3-\mathrm{NPOH}, 20 \%$ (Williams et al., 1975). About 58\% of the $\mathrm{NO}_{2}$ was found in nitro compounds that could be expected to yield 3-NPA; the 3-NPA would account for the similarity of toxic signs produced by 3-NPA and Emory milkvetch. Nitro compounds appear, therefore, to be the principal poisonous compound in the milkvetch.

We have observed that the nitro content in dried Astragalus species declines during storage. The nitro content of the Emory milkvetch used declined $28 \%$ between the summer of 1973 and 1974. We estimate, therefore, that the Emory milkvetch from $\mathrm{Ft}$. Stanton contained over $10 \mathrm{mg} \mathrm{NO} / \mathrm{g}$ when collected in 1972.

\section{Literature Cited}

Barneby, R. C. 1964. Atlas of North American Astragalus. Memoirs of The New York Bot. Garden, Vol. 13. 1,188 p.

Evelyn, K. A., and H. T. Malloy. 1938. Microdetermination of oxyhemoglobin, methemoglobin, and sulfhemoglobin in a single sample of blood. J. Biol. Chem. 126:655-662.
Harlow, M. C., F. R. Stermitz, and R. D. Thomas. 1975. Isolation of nitro compounds from Astragalus species. Phytochemistry 14:1421-1423.

Mathews, F. P. 1940. The toxicity of red-stemmed peavine (Astragalus emoryanus) for cattle, sheep and goats. J. Amer. Vet. Med. Ass. 97:125-134.

Parker, R., and M. C. Williams. 1974. Factors affecting miserotoxin metabolism in timber milkvetch. Weed Sci. 22:552-556.

Sperry, O. E., J. W. Dollahite, G. O. Hoffman, and B. J. Camp. 1964. Texas plants poisonous to livestock. Texas Agr. Exp. Sta. Bull. $1028.57 \mathrm{p}$.

Stermitz, F. R., F. A. Norris, and M. C. Williams. 1969. Miserotoxin, a new naturally occurring nitro compound. J. Amer. Chem. Soc. 91:4599-4600.

Williams, M. C., and L. F. James. 1975. Toxicity of nitro-containing Astragalus to sheep and chicks. J. Range Manage. 28:260-263.

Williams, M. C., and F. A. Norris. 1969. Distribution of miserotoxin in varieties of Astragalus miser Dougl. ex Hook. Weed Sci. 17:236-238.

Williams, M. C., F. A. Norris, and K. R. Van Kampen. 1970. Metabolism of miserotoxin to 3-nitro-1-propanol in bovine and ovine ruminal fluids. Amer. J. Vet. Res. 31:259-262.

Williams, M. C.sand R. Parker. 1974. Distribution of organic nitrites in Astragalus. Weed Sci. 22:259-262.

Williams, M. C., F. R. Stermitz, and R. D. Thomas. 1975. Nitro compounds in Astragalus species. Phytochemistry 14:2306-2308. 